\title{
Dorota Skotarczak, Otwierać, milicja! O powieści kryminalnej w PRL. Szczecin-Warszawa: Jnstytut Pamięci Narodowej, 2019, 231 stron
}

\author{
Abstract \\ Militia, Open $\mathcal{U}_{\text {p! }}$ About Crime Fiction in People's Poland. Szczecin-Warszawa: \\ Instytut Pamięci Narodowej, 2019, 231 Pages
}

In People's Poland, a distinct type of crime fiction was developed. Popular militia novels were entertaining, but also dictated attitudes towards the legal system.

Keywords: crime story, detective story, law and literature, legal awareness, Polish People's Republic

Słowa kluczowe: powieść kryminalno-sensacyjna, powieść detektywistyczna, prawo i literatura, świadomość prawna, Polska Rzeczpospolita Ludowa

Recenzowana książka jest krótką syntezą tzw. powieści milicyjnej, swoistego gatunku literackiego kultury masowej Polski Ludowej. Książka, choć niewielka rozmiarem, wymagała od Autorki ogromu pracy i zapoznania się z setkami powieści, często schematycznych utworów nie najwyższych lotów. Nie jest to jednak synteza historycznoliteracka, choć dotyczy dawnej literatury. Dorotę Skotarczak interesuje co innego, i choć wspomina o potrzebie rozważania powieści milicyjnej w kontekście całej kultury PRL, to sama podsuwa też inne tropy, konfrontując świat przedstawiony w owej literaturze z dawną rzeczywistością społeczną i polityczną. Dzięki temu - choć nie musi się to wydawać oczywiste - można dostrzec, że zarówno książka, jak i przedmiot, o którym traktuje, powinna zainteresować również badaczy dawnego prawa.

Powieść milicyjna jako gatunek odeszła w niebyt 30 lat temu wraz z samą Milicją Obywatelską i zmianą ustroju, mamy więc spory dystans czasowy względem badanego przedmiotu. Mimo to przez ten czas nie stała się obiektem szerszego zainteresowania. Wyraźnie brakowało takiego opracowania,jakie dała Danuta Skotarczak. Dotychczasowe 
prace były albo fragmentaryczne, albo powstawały jeszcze przed 1989 r., w czasie funkcjonowania gatunku - nie mogły więc obejmować jego późniejszej ewolucji.

Książka, poza wstępem i zakończeniem, składa się z siedmiu rozdziałów. Na końcu mamy wykaz cytowanych powieści (tylko cytowanych - tych wspomnianych w tekście jest więcej), bibliografię, wykaz skrótów i indeks osób. Budowa jest chronologiczno-rzeczowa czy raczej chronologiczna i rzeczowa. W pierwszym rozdziale autorka przedstawiła krótki rys historyczny polskiej powieści kryminalnej, aby na tym tle ukazać powstanie powieści milicyjnej, która kształtować się poczęła w okresie destalinizacji i odwilży. Pierwszemu etapowi (lata 1955-1961) poświęcony jest więc rozdział drugi, a kolejny obejmuje okres do 1970 r. i obalenia władzy Władysława Gomułki. Następnie analizowana jest dekada Edwarda Gierka, i wreszcie okres po stanie wojennym, aż do upadku PRL. Podziały te są przekonująco wytłumaczone, autorka przedstawia zmiany, jakie zachodziły w opisywanej literaturze kryminalnej. Pomimo zestawu cech wspólnych powieść milicyjna nie była monolitem, ewoluowała bowiem i dostosowywała się do zmieniającej się rzeczywistości - czy to warunków życia, czy zmian władz i prowadzonej przez nie polityki.

Po scharakteryzowaniu etapów rozwoju powieści milicyjnej dwa ostatnie rozdziały zaburzają konstrukcję książki. Najpierw mamy postawiony problem wpływu cenzury na powieść milicyjną - autorka sama zdaje sobie sprawę, że temat jest o wiele bardziej złożony i wymaga osobnych badań. Wreszcie na koniec dostajemy coś w rodzaju case study, czyli opis kontaktów ojca gatunku Andrzeja Piwowarczyka z bezpieką. Trudno jednak zrozumieć, czemu ma służyć prezentacja tego przypadku, bo wszystko wygląda dość nietypowo i związane jest z zainteresowaniami pisarza, który próbuje wyjechać na proces Adolfa Eichmanna, utrzymuje kontakty z izraelskimi dyplomatami czy Szymonem Wiesenthalem, wreszcie bada znaczki pocztowe łódzkiego getta... Trudno o podobnego mu innego twórcę powieści kryminalnej, a tym samym kontaktów z SB o podobnym charakterze - zresztą trudno to sobie wyobrazić w sytuacji, gdy wielu autorów (o czym jest w książce wspomniane) wywodziło się z milicji lub z nią zgodnie współpracowało.

Książka napisana jest jędrnym i barwnym językiem: autorka zadeklarowała chęć napisania dzieła naukowego („na serio"), ale o charakterze przystępnym, bardziej popularnym (s. 19). To się udało, choć mające zapewne uzasadnienie w owej „przystępności” porównywania świata opisywanego w powieściach do współczesności wyglądają mało poważnie (o tym, że i dziś trudno wyżywić się za kwotę diety krajowej albo utrzymywać rodzinę $z$ jednej pensji).

Szkoda, że porządnie wydana i dobrze napisana książka ma tak niestaranną redakcję. Natykamy się w niej na przeróżne drobne usterki - nawet fragmenty cytowanych powieści bywają oszpecone „literówkami” (Podgórki, s. 55; Postanie, s. 76). Krystyn Ziemski staje się w pewnym miejscu Krystianem Ziemskim (s. 144), ORMO zapisane jest jako OR MO (s. 101), a Miejskie Przedsiębiorstwo Handlu Mięsem jest nazwane Miejskim Handlem Mięsem (s. 89). Znaleźć można też zastanawiające powtórzenia (np. o wydawaniu powieści gazetowych w formie książkowej, s. 17 i 215). Najbardziej jednak irytuje szwankująca interpunkcja: niekonsekwentnie używana jest kursywa, cudzysłowy czy nawiasy. 
Jest to książka napisana przez historyka, autorka podkreśla więc, że interesuje ją co innego niż literaturoznawcę krytykującego powieść milicyjną za jej niskie walory literackie czy ułomny styl. Pozostawiając odmienność spojrzenia historyka i filologa, wypada wreszcie zapytać, dlaczego recenzowana książka może i powinna być intersująca dla historyka prawa? Pytanie jest tym bardziej zasadne, że problematyka prawna pojawia się w niej nie tylko marginesowo, ale też autorka potraktowała ją z dezynwolturą. A to pisze o kradzieży praw autorskich (s. 108), w innym miejscu - zapewne pod wpływem feminizacji języka - bohaterkę będącą sędzią nazywa sędziną (s. 84) - choć w powieści czytamy wprost, że piastowała „godność sędziego". Absurdalne są rozważania, czy postać należała do SB czy do kontrwywiadu, bo w tym okresie kontrwywiadem zajmowała się Służba Bezpieczeństwa (s. 101).

Za dość oczywiste należy uznać, że każda powieść kryminalna ze swej natury musi dotyczyć problemów prawnych, skoro mamy w niej i przestępstwo, i jego ściganie. Nie inaczej jest z naszą powieścią milicyjną, która kształtowała przez kilkadziesiąt lat świadomość prawną czy - jeszcze szerzej - kulturę prawną. Stanisław Barańczak, wytykając ułomności powieści milicyjnej, wskazał na jej sprzeczność wewnętrzną, bo mamy do czynienia z gatunkiem literackim ,,jednocześnie rozrywkowym i dydaktycznym, sensacyjnym i państwotwórczym, pisanym pod publiczkę i pod wytyczne $\mathrm{KC}^{\text {’22 }}$. Wspomniany dydaktyzm, państwotwórczość czy partyjne wytyczne już wskazują, dlaczego warte uwagi są owe „kryminały”. Te utwory stanowiły hybrydę - w formie łatwej i powszechnej rozrywki, spełniały też funkcję perswazyjną, narzucając czytelnikom pewne wzorce, wartości i sposoby myślenia. Dotyczyło to zwłaszcza szeroko traktowanej sfery funkcjonowania prawa, praworządności czy wymiaru sprawiedliwości.

Masowy odbiorca powieści milicyjnej podlegał oddziaływaniu tego, co chciała mu przekazać totalitarna władza. Nie chodziło tylko stosunek do przedstawicieli organów ścigania i wymiaru sprawiedliwości, ale też o kształtowanie ich wizerunku - raczej mocno odbiegającego od tego rzeczywistego. Sprawność milicji zniechęcać też powinna do wejścia na drogę przestępstwa. Same przestępstwa i osoby dopuszczające się ich są symptomatyczne - bo oprócz zbrodni popełnianych z zazdrości czy przez ludzi z marginesu mamy też przestępczość gospodarczą, jakiej dopuszczają się osoby stojące wysoko w hierarchii społecznej. Choć mamy do czynienia z fikcją, to tego typu literatura musiała nie tylko w jakiś sposób oddawać rzeczywistość (a przynajmniej tę jej część, której pokazanie było przez władze dopuszczane lub wskazane), aby znalazła czytelnika, ale poszczególne książki bywały wręcz konsultowane z milicją, której specjaliści wpływali na ich treść i właściwe oddanie realiów. Ten narzucany przez milicyjnych konsultantów sprawozdawczy styl był zresztą uważany za jeden z czynników słabości literackiej powieści milicyjnych.

Poza tym, co celowo w tych powieściach się znalazło, istotne jest też to, co jest w nich ujawniane albo mimochodem, albo nawet wbrew woli piszącego. Coś, co dawniej nie raziło, dziś jest ciekawą obserwacją. Widzimy więc choćby funkcjonowanie organów ścigania, których przedstawiciele nieraz łamali prawo, ale nigdy nie ponosili

Zeydler-Zborowski, Zygmunt. Gdzie jest Joachim Finke? Łomianki: Wydawnictwo LTW, 2011, 19.

2 Barańczak, Stanisław. Książki najgorsze i parę innych ekscesów krytycznoliterackich 1975-1980 i 1993. Kraków: Znak, 2009, 11. 
za to konsekwencji. Co więcej, można znaleźć wręcz naigrywanie się z prób zasłaniania się konstytucyjnymi prawami obywatelskimi. Wreszcie pokazana jest w powieściach cała praktyka ówczesnego życia społecznego, nie tylko jego patologie i absurdalność systemu ekonomicznego, ale też dość bezrefleksyjnie (jako niepodlegające negatywnej ocenie) podane bywają jego skutki. Nikogo nie dziwiło, a cenzura przepuszczała opisy zachowań niewiele mające wspólnego z praworządnością.

Przy wszystkich zastrzeżeniach odnośnie do korzystania ze źródeł literackich w pracach naukowych, badać można zarówno same książki, jak i to, co z sobą niosą. To wszystko nabiera też nowej aktualności dziś, gdy kształtują się wyobrażenia o peerelowskiej praworządności pokoleń, które jej nie mogą pamiętać: widać wszak swoisty renesans, zainteresowanie różnymi aspektami życia w Polsce przed 1989 rokiem, także jej kulturą - w tym również powieścią milicyjną.

Wreszcie - last but not least - powieścią milicyjną powinni zainteresować się wszyscy próbujący sił w nowych nurtach prawoznawstwa, takich jak law and literature czy estetyka prawa (w tym przypadku przede wszystkim estetyka przestępstwa) ${ }^{3}$.

Praca Doroty Skotarczak może i powinna stanowić zarówno inspirację, jak i punkt wyjścia dalszych, szczegółowych badań nad poszczególnymi aspektami powieści milicyjnej. Warto, by pośród takich badań nie zabrakło głosu historyków prawa.

3 Por. Zeidler, Kamil. Estetyka prawa. Gdańsk-Warszawa: Wydawnictwo Uniwersytetu Gdańskiego, 2018; Wójcikiewicz, Józef. Piękno przestępstwa. Prolegomena do estetyki sądowej. Kraków: Wydawnictwo Uniwersytetu Jagiellońskiego, 2020. 